\title{
PAX DIGITALIS. ŻYCIE W WIEKU CYFROWEJ HIPERKOMUNIKACJI
}

\author{
Pax digitalis. Life in the age of digital hyper-communication
}

Streszczenie: Artykut jest próba krytycznej analizy dyskursów i stanowisk w kwestii społecznych skutków akceleracji rozwoju technologii cyfrowych. Nakreślono w nim tren$d y$, których ziarna kietkowaty już przed COVID-19, a inne zostaty dopiero posiane przez pandemię. Uwaga powinna się w najbliższym czasie skupić na nowych azymutach myślenia. To sa wytaniajace się pytania badawcze i odpowiedź na nie wymaga pozyskania empirii, na bazie której powstanie nowa wiedza. Ogólnie znane sa wektory zmian, na podstawie których można cokolwiek przewidywać, ale nie wiadomo, jaka będzie ich wypadkowa, jaki kształt zmian i jak je ewaluować. Zmienność i przyspieszenie to dwa megatrendy wynikajace z hiperkomunikacji i technologizacji życia. W publikacji skoncentrowano się na dość arbitralnie wybranych zagadnieniach zwiazanych z funkcjonowaniem technologii cyfrowych w spoleczenstwie.

Słowa kluczowe: hiperkomunikacja, technologie, cyfryzacja, sieci, Internet

Abstract: This article is an attempt to critically analyse discourses and positions on the social impact of accelerating digital development. It outlines trends whose seeds were already sprouting before COVID-19, while others have only been sown by the pandem$i c$. Attention should focus on new directions of thinking in the near future. These are emerging research questions, and answering them requires the acquisition of empirics from which new knowledge will emerge. Vectors of change are generally known, on the basis of which anything can be predicted, but it is not known what their resultant will be, what shape the changes will take, and how to evaluate them. Volatility and acceleration are two megatrends resulting from hyper-communication and the technologisation of life. The publication focuses on certain issues, rather arbitrarily selected, which are related to the functioning of digital technologies in society.

Keywords: hyper-communication, technology, digitisation, networks, Internet

1 Dr hab. Kazimierz Krzysztofek, prof. USWPS - Instytut Nauk Społecznych, Uniwersytet SWPS w Warszawie, e-mail: kkrzysz1@swps.edu.pl, ORCID: 0000-0002-1772-8861 


\section{Wstęp}

Na naszych oczach rodzi się cyfrowe społeczeństwo hiperkomunikacyjne, które jest efektem synergicznym szybkości połączeń, ich masowości i potęgowego rozkładu relacji społecznych, zwłaszcza zmediatyzowanych. W istotny sposób transformuje to struktury społeczne, choć mamy jeszcze za mało empirii, aby orzec, co wynika z nałożenia nowych technologii infokomunikacyjnych na zastane sieci społeczne: na ile te sieci „oswoją" nowe technologie, a w jakim stopniu zostaną przez nie zdominowane.

Szybkość wypełnia ducha epoki. Była ona wymuszana przez potrzebę pokonywania przestrzeni. Gdy szybkość przekazu informacji stawała się coraz ważniejsza w obrocie gospodarczym, nabierało znaczenia uniezależnianie przesyłu danych i informacji od fizycznego przemieszczania się ludzi transportujących informację czy innych fizycznych nośników.

Do hiperkomunikacji prowadziła długa droga. Wynalazki przyspieszały porozumiewanie się, obieg myśli. Mowa jako rozwinięty system komunikacji symbolicznej pozwoliła na organizowanie się ludzi w zasięgu donośności głosu. Wynalezienie pisma ideograficznego, a później alfabetu pozwoliło na szybszy transport myśli w większych skupiskach ludzi; dzięki drukowi mogły powstać państwa i imperia, zaś media elektroniczne zafundowały nam społeczeństwo globalne.

Wiadomość o postawieniu stopy na wyspie Hispaniola w 1492 r. przez Kolumba wędrowała na królewski Wawel blisko dwa lata. Ponad trzy wieki później informacja o śmierci Napoleona na Wyspie św. Heleny dwa miesiące. W następnych dekadach szybkość przekazu informacji stawała się kluczowym składnikiem powodzenia. Telegraf, a nieco później telefon stały się kamieniami milowymi w procesie tego przyspieszania. Analogicznie podobną rolę odegrały w transporcie fizycznym kolej, parowiec, automobil i samolot. Następował proces kumulacyjny: coraz większa szybkość wymuszała w następnym etapie jeszcze większą szybkość.

W pogoni za nią osiągano postęp wykładniczy, co niosło ze sobą ciągłą zmianę społeczną. Zmiana następuje szybciej niż refleksja o niej. Dyktatura czasu - chronokracja - wchodzi w alians z dromokracją - dyktatem szybkości, a jej najważniejszym wymiarem jest koneksjonizm - łączenie wszystkiego ze wszystkim. Pomnożenie masowości przez szybkość daje szybkościoprzestrzeń (l'espace-vitesse), jak to proponuje nazwać Paul Virillo. Większość informacji przechodzi dziś przez podłączone komputery - „maszyny tysięcy zastosowań”, jak je nazywa Neal Postman, więc 
posługiwanie się nimi staje się umiejętnością tak podstawową jak umiejętność czytania i pisania w epoce przemysłowej.

Kult szybkości i gorączka czasu osaczają nas na każdym kroku. Technologie tkają coraz gęstsze sieci, wymuszając coraz większą mobilność, intensyfikując komunikację między sobą i potęgując rozkład relacji społecznych. Dzięki sieciom mobilność ludzi jest coraz mniej zależna od fizycznej ruchliwości. Dlatego systemy telekomunikacyjne rozwijają się szybciej niż transportowe, zwłaszcza w czasie pandemii. Dziesięciokrotne zwiększenie gęstości sieci to teoretycznie stukrotny przyrost punktów intersekcji (przecięcia). Stopień komplikacji rozwoju społeczno-ekonomicznego zmusza do użycia coraz szybszych narzędzi, bez których nie jest już możliwe zgromadzenie, przetworzenie i zużytkowanie olbrzymiej „infomasy”, zapanowanie nad szumem informacyjnym przy pomocy tradycyjnych nośników informacji i narzędzi komunikacji. Mózg ludzki przestaje już wystarczać w swej funkcji kondensatora pamięci, arytmetycznego kalkulatora i procesora, a informacje zmagazynowane na tradycyjnych nośnikach („,pamięć skoroszytowa") stają się trudne do zoperacjonalizowania i efektywnego wykorzystania jako zasób wiedzy i narzędzie optymalizacji decyzji.

Eksplozja technik komunikacyjnych w czasach najnowszych musiała spowodować niebywałe zagęszczenie informacji, intensyfikację ich przekazu na skalę każdego społeczeństwa oraz w wymiarze globalnym. Szacuje się, że na skutek postępu technicznego w ostatnim stuleciu prędkość przesyłania informacji wzrosła ponad 100 milionów razy. Oto dlaczego słuszny jest pogląd, że człowiek współczesny żyje w świecie hiperkomunikacji i informacji totalnej, która zmienia jego środowisko fizyczne i kulturowe. Tempo zmian jest tak olbrzymie, że 1 rok Internetu to 7 lat każdego innego medium - pierwsze $50 \mathrm{mln}$ słuchaczy radio osiągnęło po 38 latach, telewizja - po 13, komputer - po 16. Internet potrzebował tylko 4 lat.

Nie ma sektora, który by zmieniał się szybciej niż IT. Konsumujemy coraz więcej symboli, a one krążą szybciej niż dobra materialne. Coraz szybsze wyszukiwarki bombardują nas coraz większą masą danych i informacji. A przecież należałoby coś powiedzieć o telefonii mobilnej, która przerabia każdego z nas w globalny terminal. Smartfony niesamowicie zagęszczają tkankę połączeń między ludźmi. Chyba brak nam ciągle dystansu do tego najważniejszego niezbędnika naszych czasów - „wtyczki do świata”.

Społeczeństwo w wieku hiperkomunikacji to $24 \mathrm{~h}$ society. Życie w nim jest dla ludzi aktywnych superciekawe: dostarcza mnóstwa doznań i przeżyć, tysięcy atrakcji, wśród których Internet jawi się jako sezam. 
Szkoda czasu na sen. Rosnąca liczba kanałów informacyjnych stwarza odbiorcy sytuację hiperwyboru. W ciągu kilkunastu godzin czuwania, którymi może on rozporządzać, otrzymuje niezwykle dużo ofert.

\section{Hiperkomunikacja w wieku pandemii COVID-19}

Hiperkomunikacja akcelerowała na długo przed pandemią, ale w jej warunkach wręcz eksplodowała. Żyjąc „pod okupacją" COVID-19, musimy się pokusić o systematyczne ujęcie problemu wpływu hiperkomunikacji cyfrowej na kształty społeczeństw. Trendy cywilizacyjne zależeć będą od tego, jaką skalę osiągnie nowy ład (a może nieład) cyfrowy, który staje się nowym społecznym systemem operacyjnym.

W dotychczasowych badaniach sieci formułowano wiele hipotez, m.in. taką, że Internet sprzyja pogłębianiu się więzi społecznych; więzi przezeń zawarte mogą być równie bliskie, jak te w świecie offline. Internet stanowi narzędzie podtrzymywania słabych więzi społecznych, które bez jego udziału zostałyby zerwane. Aktywność w sieci komputerowej nie zastępuje kontaktów bezpośrednich, lecz dużo częściej uzupełnia inne typy komunikacji. Społeczna izolacja jednostki rośnie wraz z użyciem Internetu bądź na odwrót - sieć, która sprzyja indywidualizacji, zwiększa jednocześnie aktywność społeczną. W relacji „sami - razem” Internet kreuje nowe sposoby bycia "razem" i bycia "samymi”.

Im większa gęstość sieci, tym bardziej - zgodnie z prawem potęgowego rozkładu relacji - działalność każdego użytkownika wpływa na innych. Można to sprowadzić do trzech scenariuszy: technologie cyfrowe a) nadbudowują "coś" nad społeczeństwem; b) wchłaniają społeczeństwo; c) są przez społeczeństwo wchłaniane. Przez najbliższe lata, a może całe dekady, nauki społeczne będą prowadziły wiele badań i analiz w poszukiwaniu odpowiedzi na pytanie: dokąd prowadzi nas Internet. W zależności od tego, ile o nim wiemy, jego naturze i etiologii, możemy powiedzieć, ile wiemy o społeczeństwie, czy też o tym, jak je inaczej nazwiemy. Przed socjologią staje pytanie, czy świat cyfrowy jest uzupełnieniem społeczeństwa, nową społecznością, a może nowym sztucznym żywiołem albo też Nową PlaNETą, której nie można z niczym porównać. Tego jeszcze nie wiemy, ale można się pocieszać, że druk czekał kilkaset lat, aby go oswoić i zdać 
sobie sprawę z wielkości zmiany instytucjonalnej, społecznej, ekonomicznej, politycznej i kulturowej - generalnie: cywilizacyjnej - jaką przyniósł.

Przed kilkudziesięciu laty Harold Innis (1951) pisał, że w każdej epoce dziejów ludzkich społeczeństwo, gospodarka, kultura posiadały system komunikacji oparty o dominujące medium. W każdym społeczeństwie istniały punkty węzłowe, w których akumulowano i przekazywano wiedzę o gospodarowaniu, kulturze, polityce itp. Przez wieki takimi węzłami były szkoły, uniwersytety, biblioteki, instytucje kościelne (zwłaszcza niektóre zgromadzenia zakonne, jak jezuici, cystersi, benedyktyni), później media masowe (Innis 1951). W czasie pandemii funkcję takiego megawęzła pełni w rosnącym stopniu Internet, cokolwiek o nim sądzimy. Ci, którzy sprawują kontrolę nad tymi węzłami, posiadają również władzę. W społeczeństwie masowym takimi punktami były wyłącznie duże instytucje hierarchiczne: rządy państw, przedsiębiorstwa, koncerny medialne itp. Internet, w tym zwłaszcza Internet rzeczy, sprawia jednak, że punkty takie ulegają rozproszeniu i zwielokrotnieniu. $W$ rezultacie dostęp do wszelkich informacji jest łatwiejszy, mniejsza jest asymetria w dziedzinie informacji i wiedzy, a instytucje hierarchiczne tracą pozycję informacyjnego monopolu.

Socjolog musi sobie zadać pytanie, czym jest dzisiaj struktura społeczna i z jakimi grupami społecznymi mamy do czynienia. Nie wystarczy już kanoniczny podział na „wspólnotę" i „społeczeństwo”. Barry Wellman (2001: 227-252) i Manuel Castells (2011) proponują kategorię indywidualizmu sieciowego - prywatyzacji uspołecznienia, bez czego nie da się zrozumieć fenomenu sieci. Członek takiej społeczności jest jej cząstką, ale zarazem autonomicznym węzłem (konektorem), samodzielnie zarządzającym swymi relacjami w sieci, niejako prywatyzującym społeczność, w której uczestniczy. W takim rozumieniu wspólnota jawi się jako indywidualna, niepowtarzalna sieć każdego nettera, w obrębie której nie ma konieczności kontaktu między wszystkimi jej członkami. Zdaniem niektórych badaczy indywidualizm sieciowy jako nowy wzorzec relacji zbiera żniwo w postaci epidemii samotności. Aktywność w wirtualu może być kompensacją samotności, ale nie dla wszystkich, to zależy od osobowości, poziomu ekstrawersji/introwersji, umiejscowienia kontroli (wewnątrz- i zewnątrzsterowność). Zależy także od intensywności relacji społecznych. W społeczeństwach o względnie niskim poziomie kontaktów społecznych (low contact level society) samotność doskwiera w mniejszym stopniu niż w społeczeństwie o wysokim poziomie kontaktów (high contact level 
society). W obu tych typach społeczeństw inaczej funkcjonuje zdalna praca, nauczanie i inne. To by wymagało empirycznej weryfikacji, na ile te typy są idealne, a na ile realne.

Z pięciu głównych orientacji aktywności życiowej: ekspresyjnej, ludycznej, poznawczej, normatywnej i narzędziowej indywidualizm sieciowy najbardziej dotyka normatywnej, można mówić o chaosie normatywnym, prywatyzacji moralności, osłabieniu kontrolnych funkcji grup i instytucji społecznych czy personalizmie narcystycznym („patrzcie na mnie”). Technosfera dominuje nad logosferą.

W warunkach pandemii rośnie migracja wielu działań użytkowników do sieci, a to wymaga zastanowienia się nad tym, czy indywidualizm sieciowy, który jest podstawą spersonalizowanych sieci międzyludzkich, zapewni na dłuższą metę budowanie relacji cechujących się dobrowolnością, stałym podtrzymywaniem i potwierdzaniem zaangażowania, oraz relacji będących dla jednostki źródłem pozytywnej samooceny oraz umożliwiających zaspokojenie potrzeby afiliacji, zakorzenienia i bezpieczeństwa. Chodzi o taki indywidualizm, który czyni z jednostki egopolis, stawia ją w centrum relacji społecznych, czyni ją ich menadżerem.

Największy wpływ na to mają technologie mobilne, zwłaszcza wspomniany smartfon. Zwykło się narzekać, że ludzie są od niego uzależnieni, nie wyobrażają sobie bezeń egzystencji. I to jest prawda, ale trzeba też na to spojrzeć z drugiej strony: smartfon to dziś najważniejsze narzędzie osobistej logistyki, zarządzania codziennością. Bez niego jesteśmy ślepi, pozbawieni koordynacji przestrzenno-czasowej. Towarzyszy temu rewolucja autonomiczna: coraz więcej urządzeń raz zaprogramowanych może się częściowo obywać bez człowieka. Na myśl przychodzą tu samochody bez kierowcy, ale dotyczy to generalnie smart machines. Następuje szybki rozwój tej tendencji związanej z Internetem rzeczy i przemysłem czy też gospodarką 4.0. Wniosek z pandemii rysuje się klarownie: skoro ludzie zarażają się wirusami i nie jesteśmy w stanie temu zapobiec - a to chwyta za gardło całą gospodarkę światową - to trzeba zaangażować maszyny, które są odporne, czyli przyspieszać automatyzację/robotyzację produkcji i usług. Stąd rosnące znaczenie firm wysokich technologii, netokratów spod znaku GAFA (Google-Amazon-Facebook-Apple). Obecnie mówi się już o „Wielkiej Dziewiątce”, bo do korporacji amerykańskich dołączyły potężne koncerny chińskie, m.in. Tencent, Baidu, Alibaba, Huawei, WeChat (Webb 2019). Co prawda maszyny nie konsumują, a ktoś musi konsumować, skoro trwa produkcja, ale z podatku od robotów 
będzie można sfinansować powszechny dochód podstawowy. W fabryce autonomicznej będzie - już w wielu miejscach jest - garstka ludzi w nadzorze, którzy - jeśli to będzie konieczne - zachowają odstęp 2 metrów. Bo na jakiś czas będziemy skazani na "gospodarkę 2 metrów".

Żadna praktyka społeczna dokonująca się w cyfrowym świecie nie będzie już taka sama jak w świecie analogowym. Rośnie liczba działań i zdarzeń społecznych, które są digital native - mają postać wyłącznie cyfrową. Bez cyberprzestrzeni by ich po prostu nie było. Ratunkiem jest Internet, choć wylewa się nań fala krytyki. Skłonni byliśmy go postrzegać jako narzędzie komunikacji, rozrywki, ekspresji, źródło informacji, wiedzy, przestrzeń do lokowania własnych zasobów (wiedzy, emocji itp.) i korzystania z zasobów umieszczanych tam przez współużytkowników. Dziś okazuje się on czymś o wiele większym - infrastrukturą krytyczną, niezbędną do przetrwania, jak sieci wodociągowe, kanalizacja, elektryczność. Gdyby nie Internet, to mielibyśmy zapewne powtórkę „czarnego czwartku" (24 października 1929 r.).

To jest z pewnością triumf wirtualu: podtrzymuje on więzi społeczne, pracownicze, umożliwia zakupy, świadczenie pracy przez Skype, telekonferencje. Cyfryzowane będzie wszystko, co możliwe, co prowadzi do hybrydyzacji przestrzeni cyberfizycznej. „Życie w digitalu” nie jest już kwestią wyboru. Paradoksalnie społeczeństwo zakodowane (przez PIN, loginy, hasła dostępowe) jest jednocześnie transparentne (Brin 1998). Odpowiednie służby i nie tylko, także biznes, bardzo wiele o nim wiedzą.

Przeniesienie większości orientacji aktywności ludzi do sfery online powoduje, że relatywnie zmniejsza się skala komunikacji bezpośredniej, a wzrasta zapośredniczenie relacji społecznych. Świat staje się jednym wielkim laboratorium, w którym aktywność ludzi jest policzalna, wychwytywane są ze „złóż” danych korelacje niedostępne analitykom. Oczywiście wymaga to potężnej mocy obliczeniowej, komputer kwantowy staje się koniecznością, aby wydobywać i przetwarzać rosnące złoża danych w cyfrowej noosferze. Nowe bogactwo świata jest w zasięgu ręki (myszki). Efektem tego jest akceleracja procesów: człowiek wszystkiego uczy się sam i/lub z pomocą nauczyciela, ale musi na to poświęcić wiele czasu. Miliony maszyn, komputerów można dzięki aplikacjom i programom nauczyć w trybie deep learningu niemal natychmiast, a coraz częściej uczą się już same (np. algorytm Google'a AlphaGo-Zero, który pokonuje mistrzów najbardziej inteligentnych gier strategicznych). To niesamowicie przyspiesza procesy produkcji, wymiany, komunikacji. Wchodzimy 
w wiek dromokracji. Za przyczyną wszechpołączalności świat stał się jednym wielkim zderzaczem hadronów, w którym byty ludzkie i nie-ludzkie są cząstkami elementarnymi i którym nadaje się wielką szybkość zderzania. Tą metaforą posłużył się w swojej książce Michel Houellebeck.

Może się pogłębić luka ludzka między ludzkim umysłem a superinteligencją. Jeśli będzie się jeszcze opłacać inwestować w człowieka, to w tę garstkę supertalentów, którzy będą programować inteligentne systemy i zarządzać nimi. Michael Anissimov (2015), transhumanista i autor bloga Accelerating Future, uważa, że radykalnie rozwinięta ludzka inteligencja (IA - Intelligence Amplification) może się stać znacznie potężniejsza od sztucznej inteligencji (AI - Artificial Intelligence). Realistycznym celem wzmacniania inteligencji człowieka będzie bowiem tworzenie nie Einsteinów, a super-Einsteinów - ludzi znacznie bystrzejszych niż jakikolwiek człowiek żyjący dotychczas na Ziemi, zdolnych kontrolować nawet najbardziej inteligentne maszyny. Niekoniecznie. Z chwilą pojawienia się sztucznej inteligencji ludzie będą musieli przejść od myślenia biologicznego do myślenia hybrydowego - jak nazywa je Ray Kurzweil. Takiego, które połączy potencjał człowieka i maszyny, mózgu i procesora, białka i krzemu.

Użytkownicy cyfrowi mogą hasać po nadzorowanym przez algorytmy polu, nie mogąc poza nie wyjść. Nie będzie się opłacało inwestować w "człowieka z ulicy", bo lepsze efekty przyniesie inwestowanie w sztuczną inteligencję. Yuval Noah Harari pesymistycznie przepowiada, że nie będzie szczególnego zainteresowania władzy dbaniem o kondycję zdrowotną i umysłową mas, bo nie będą one potrzebne ani jako wytwórcy, ani np. żołnierze; wytwórstwem i wojowaniem zajmą się roboty, te "ucieleśnione" i te czysto software'owe. Niewiara w możliwości człowieka przełoży się na delegowanie norm postępowania na maszyny i rozwiązania inżynieryjne. Nie jest to nowość: od dziesiątków lat „śpiący policjanci” na ulicach wymuszają przestrzeganie limitów prędkości pojazdów.

Rozszerzający się Internet jest nowym wszechświatem. Wielki Wybuch trwa. Przez dziesięciolecia, a może stulecia człowiek marzył o zasiedleniu obcych planet. To się na razie nie spełniło, ale ziszcza się na naszych oczach sen o emigracji na PlaNETę Internet. Algorytmy wdzierają się we wszystkie szczeliny życia. Gdy pojawi się sensoryczne sprzężenie zwrotne, możliwość dotykania, wąchania, smakowania (Stawska 2021), odczuwania bytów kreowanych cyfrowo, to nastąpi dokończenie cyfryzacji wszystkiego, co możliwe, hybrydyzacja przestrzeni. Internet będzie Omninetem; nie wszystko 
zostanie oczywiście ucyfrowione, ale niemal wszystko, co istnieje, fizycznie będzie mieć cyfrową reprezentację.

„Wirtual" i „real" to nie dwa światy równoległe, dwie odrębne rzeczywistości, a jedna, hybrydowa, cyberfizyczna. Rosnąca migracja działań ludzkich do sieci stała się koniecznością. Już przed COVID-19 życie w świecie cyfrowym nie było kwestią wyboru, a dziś jest koniecznością w dwójnasób. Pandemia wymusza wchodzenie do cybeprzestrzeni, wszędzie trzeba się logować, a jeśli nawet wiele osób się temu opiera, to i tak cyfryzacja ma olbrzymi wpływ na ich życie, ponieważ coraz więcej dóbr i usług występuje w wyłącznie formie digitalnej. Algorytmy przejęły kontrolę, jak to określił w tytule swej książki Lev Manovich: Software takes command (Manovich 2013). Ma to wymiar polityczny².

Wyłania się przekonanie ludzi polityki, biznesu i data scientists, że większość problemów społecznych da się rozwiązać dzięki nowoczesnym technologiom, co Evgeni Morozov nazywa solucjonizmem i co ma oznaczać swoistą laboratoryzację społeczeństwa (Morozov 2013). Solucjonizm wedle tego publicysty jawi się jako system już nie tyle społeczny, ile socjotechniczny, w którym kluczem do wszystkiego jest odpowiednia liczba kliknięć. To zjawisko mieści się w logice rozwoju cywilizacji zachodniej od fazy industrializmu. Pokusa wykorzystania nauki i techniki w inżynierii społecznej istniała od początku ery maszyn. Miała ona zapewnić przewidywalność oraz kontrolę praktyk i procesów społecznych, powściągnięcie ich żywiołowej i potencjalnie destrukcyjnej natury.

Co z tego wynika? Przede wszystkim to, że pandemia przyspieszyła przechodzenie ze starego przemysłowego systemu operacyjnego na nowy, cyfrowy (Rainie, Wellman 2012). Jest to nowy kod, w którym komunikują się ludzie i byty nie-ludzkie. To język cyfrowy: w ciągu kilkunastu lat przyniósł on nowe zjawiska, które jeszcze 30 lat temu nie istniały. Ich nazwy to wskaźnik zmian w życiu ludzi i społeczeństw. Warto przytoczyć np.: chatowanie, updejtowanie, googlowanie, blogowanie, cyberrandkowanie, tweetowanie, szerowanie (od share).

2 Za mało zwraca się uwagi np. na polityczny potencjał Twittera, za pośrednictwem którego rządzący mogą zrobić wielką różnicę na plus i na minus. Jak trafnie zauważa Łukasz Walewski: impulsywnie, bez doradców, nie zawsze na trzeźwo. Tak za pomocą Twittera komunikują się dziś ze światem władcy atomowych imperiów, z Donaldem Trumpem na czele. Do poważnego międzynarodowego kryzysu może doprowadzić jeden wpis przy porannej kawie. A wszystko to w 280 znakach (Zalewski 2020). 
Każdy ład społeczny jest swoistym systemem operacyjnym. Gra toczy się o wysoką stawkę - kontrolę nad nowym systemem. Oczywiście będą ją sprawować właściciele algorytmów. Jest on przeniesieniem logiki Internetu na całe społeczeństwo, nałożeniem nowej infrastruktury cyfrowej na dotychczasowy system społeczny ukształtowany przez instytucje nowoczesnego społeczeństwa przemysłowego. Nowy Społeczny System Operacyjny (dalej: NSSO), jak go definiują Rainie i Wellmam, to oprogramowanie zarządzające już niemal całym społeczeństwem, tworzące środowisko uruchamiania i kontroli działań ludzi, zarządzania nimi. Siłami sprawczymi NSSO są: Internet szerokopasmowy, w tym Internet rzeczy, serwisy społecznościowe oraz urządzenia mobilne, Big Data i inne.

Dokonują się procesy zmiany instytucjonalnej: zanikanie jednych instytucji, utrzymywanie się instytucji typu "Zombie", transformowanie innych i powstawanie nowych. W społeczeństwie regulowanym przez cyfrowy system operacyjny inaczej zachowują się znane kategorie socjologiczne: władza, status (inne wyróżniki statusowe w wirtualu niż w realu), przywództwo, więzi, grupy, odniesienia, znaczący inni, wykluczenie itp. Współdzielenie analizowane z tej perspektywy to część szerszego procesu, który rozpoczął się od kultury współdzielenia dzięki powstaniu internetowych platform komunikacyjnych, a rozciąga się na inne sfery: wytwarzanie energii, logistykę, edukację, pracę i inne. Mówiąc krótko, NSSO jest nakładką cyfrową na system społeczny, mediatyzując dzięki temu wymianę (nabywanie, zbywanie, nieodpłatne świadczenie) niematerialnych dóbr i usług, ale także dostarczając platform zapośredniczających wymianę materialnych dób i usług.

W znacznej części te praktyki to nie współdzielenie, a model biznesowy oparty o platformy internetowe, które niczego nie wytwarzały, a jedynie zapośredniczały, jak Uber, AirBnB, Netflix i wiele innych (obecnie to się zmienia: platformy stają się producentami). Jednocześnie mamy autentyczne współdzielenie w postaci samozaopatrzenia poznawczego, informacyjnego, ludycznego itp., dokonującego się poza korporacjami i rynkiem. NSSO daje siłę zwłaszcza "tubylcom sieciowym” odznaczającym się wysokimi kompetencjami w networkingu. Większość to użytkownicy działający i rozwijający się intelektualnie w ramach algorytmów. To grupa, w której lokują się masy zwykłych użytkowników niedysponujących wielką siłą sprawczą, ale przeświadczonych, że dzięki technologiom mobilnym mają moc i w pewnym sensie mają rację - za ich pośrednictwem 
ujawnia się bowiem siła hiperkomunikacji. Rośnie poczucie podmiotowości indywidualnego użytkownika w sieci. Korporacje udostępniają użytkownikom „za darmo” technologie współpracy i współdzielenia, zyskując w ten sposób złoża danych, zawartość, relacje i inne. To jest waluta, którą płacą użytkownicy.

NSSO wiele obiecuje, ale też rodzi problemy związane z prywatnym posiadaniem jego infrastruktury. Ewolucja NSSO i Internet, na substracie którego ten system został stworzony, podążają drogą wcześniejszych technologii: druku, telekomunikacji, mediów elektronicznych, na początku działających w rozproszeniu, pluralizmie rynku, ale z czasem znalazły się pod kontrolą korporacji je koncentrujących, a także regulacji rządowych. Internet, choć narodził się jako projekt rządowy w USA, w jeszcze większym stopniu niż wcześniejsze technologie zależy od biznesu, bo ma największy udział w tej puli. Amerykański badacz Internetu Tim Wu (2011) obawia się, że to korporacje-netokracje mają w ręku główny przełącznik - Master Switch, dzięki któremu mogą go wyłączyć. Choć wydaje się to nierealne, bo to byłoby dla nich samobójstwem, to jednak posiadają taką możliwość, przynajmniej częściowej dezaktywacji elementów sieci i wykluczania użytkowników (co można uznać za cyfrową formę banicji). Jest to szerszy problem kontroli nad sieciami. Kiedy ich nie było, każdy miał władzę nad narzędziami, własną „wygódką”, lampą naftową, dostępem do wody (studni). Fragmenty sieci można wyłączyć; wcześniej można było to robić lokalnie, obecnie jest to możliwe na skalę globalną. Mówi się coraz częściej o technologicznej suwerenności oznaczającej, że powinno się w możliwie jak największym stopniu polegać na własnym sprzęcie i oprogramowaniu, niebędących „czarnymi skrzynkami”, w których mogą być zaszyte jakieś luki w zabezpieczeniach. Chodzi o kontrolę nad technologiami, ochronę danych przed ich przejęciem. To staje się tak ważne jak pewność, że nikt nam nie odetnie prądu.

To, co nazywamy społeczeństwem, w połączeniu z technologiami jawi się jako maszyna społeczna - system, w którym uczestniczą działające automatycznie podsystemy ludzkie i cyfrowe (Shadbolt 2013: 200-205; Smart, Shadbolt 2014). Jest ona sztucznym, świadomie zaprojektowanym i skonstruowanym, niestanowiącym efektu spontanicznych procesów i nieposiadającym odpowiedników w zastanej rzeczywistości społecznej, układem ról i relacji, który funkcjonuje w przewidywalny, regularny sposób (Afeltowicz, Pietrowicz 2013). W tym rozumieniu maszynami społecznymi są Google, Amazon, Facebook i inne. Są to szeroko rozumiane 
media wykorzystywane do kreowania relacji między ludźmi oraz między ludźmi i rzeczami.

Do tego gatunku można zaliczyć eksperyment, jaki stworzono w Chińskiej Republice Ludowej. Polega on nie na wymuszaniu, a stymulowaniu lojalności czy wręcz posłuszeństwa wobec władzy przez udział w grze, która nagradza. Nazwano to kredytem społecznym (więcej: Sesame Credit 2016; Krzysztofek 2018: 73-110), a chodzi o osiągnięcie wyniku, który jest wskaźnikiem "dobrego obywatela". Taki obywatel jest sterowany behawioralnie, gratyfikowany dobrodziejstwami, na które wpływ ma władza, a jest on znaczny. Stymulować odpowiednie zachowania mają oczywiście nie tylko nagrody, lecz także kary, np. za utrzymywanie niepożądanych kontaktów z obywatelami "gorszej kategorii” (niskopunktowanymi), czy co byłoby jeszcze bardziej naganne - z dysydentami, albo tylko poszukiwanie informacji o takich osobach. Jest $\mathrm{w}$ tym pewna kalkulacja - liczenie na pedagogikę obywatelską: wywieranie wpływu przez „lepszych" obywateli na "gorszych", żeby ci drudzy nie "psuli hipoteki”, nie obniżali wyniku tym drugim.

Pytanie, czy model chiński - efektywny autorytaryzm - nie jest w warunkach zagrożeń bardziej atrakcyjny dla świata niż zachodni, liberalny. Autorytaryzm ma tę zaletę, że pozwala centralizować big data i szybko reagować na zagrożenia. Istnieje oczywiście ryzyko, iż jest on bardziej podatny na paraliż, gdy jakiś jego element zawiedzie. Wiele zależy od tego, kto wygra wojnę o 5G. W wersji chińskiej społeczeństwo 5.0 to, jak lapidarnie to określa znawca Państwa Środka, Kai Strittmatter, katapulta dla gospodarki plus kontrola i samoinwigilacja, turbonapęd i prześwietlanie mózgu do ostaniego neuronu (Strittmatter 2020). W wojnie o 5G chodzi także o to, na czyich serwerach mają być dane o użytkownikach, które są walutą XXI w. W rywalizacji o przewagę w łańcuchu wartości - wyżej w nim jest to, co cyfrowe - powstanie zapewne fala innowacji, niektóre mogą być przełomowe. Ameryka nie jest przegrana, ma swój kwartet data corporations - GAFA, choć jak wspomniano, zagraża im ekspansja chińskich korporacji technologicznych ${ }^{3}$.

3 Ale to amerykańska firma, SpaceX Elona Muska, buduje Starlink - telekomunikacyjny system satelitarny, mający docelowo składać się z ok. 12000 satelitów umieszczonych na niskiej orbicie okołoziemskiej na 3 wysokościach - 340, 550 oraz 1150 km nad Ziemią. Oczekuje się, że ten system, który będzie substratem dla nowej generacji Internetu, zwiększy skokowo potencjał intelektualny ludzkości (Kosmiczny internet coraz bliżej 2020). 
Chiński system nadzoru ujawnia nową prawdę o społeczeństwie w wieku digitalizacji. Przez większość historii władza centralna nie mogła bliżej poznać obywatela (wcześniej poddanego) tylko dlatego, że nie była w stanie zebrać i przetworzyć wielu danych i informacji o nim. Byli ludzie, znający nas bardzo dobrze, ale zazwyczaj byli to ci, których interesy zbiegały się z naszymi. Teraz dochodzimy do punktu, w którym jakiś system działający daleko od nas może znać nas lepiej niż nasi bliscy, a nawet my sami siebie, choć nasze interesy niekoniecznie są zbieżne. To rodzaj władzy, która nigdy wcześniej nie istniała, umożliwiająca reżymom totalitarnym i autorytarnym robienie rzeczy wcześniej po prostu technicznie niemożliwych. Od tysięcy lat ludzie postrzegali życie jako dramat podejmowania decyzji. Niektóre z nich dotyczą spraw drobnych, jak to, co jeść na śniadanie, a inne są poważne, np. z jakim partnerem się związać - teraz jesteśmy wyręczani poprzez algorytmy i lubimy to (Sumpter 2019). Szacuje się, że w ciągu najbliższych 2 lat 50\% decyzji będzie podejmowane przez algorytmy. Kultura zatem to już nie tylko zestaw wartości i norm, lecz także algorytmy z zaszytymi w nich normami, które regulują zachowania ludzi (Domingos 2017).

Wkraczamy w epokę digital governance. Gamifikacja, głód natychmiastowej gratyfikacji, sterowanie ludźmi przez wzmocnienia behawioralne, deficyt stymulacji wewnętrznej i nadmiar zewnętrznej (przebodźcowanie), ciągłe poszukiwanie pobudzenia (sensation seeking behaviour), "pragnienie pragnienia", nazywane kieratem hedonicznym, pozwalają systemowi czerpać siłę z automonitoringu/samonadzoru obywateli i konsumentów, którzy stają się strażnikami samych siebie. Ten samonadzór to „skwantyfikowane ego" (quantified self, life logging), życie pod nadzorem chipa. Coraz tańsze technologie, stacjonarne i mobilne, pozwalają każdemu monitorować siebie: oszczędności, własne zasoby, zdrowie, deskilling i inne. Strach przed utratą zdrowia, kompetencji i wiedzy skłania ludzi do tego, że sami zaopatrują się $\mathrm{w}$ te urządzenia, personalizują je i przystosowują do nich (Attali 2008). Samonadzór staje się stylem życia jako model potrzeby osiągnięć tych, którzy chcą w tym systemie uczestniczyć i dać się mierzyć na jednej podziałce - produktywności i lojalności, przy okazji dostarczając gigabajtów danych o sobie. $W$ rezultacie mniej wiemy o sobie - bo to umyka naszej świadomości i pamięci - od tych, którzy te dane pozyskują, agregują w odpowiednie profile osobowościowe, a często nimi - poza naszą wiedzą i zgodą - handlują. Transfer cennych danych trwa już od dawna i przyspiesza. Portal 1000memories.com oszacował, jaką część danych 
i informacji o sobie Amerykanie pozostawiają w sieci: w przypadku 65-latków to tylko $12 \%$, ale 45 -latkowie zdeponowali w internecie już $56 \%$ danych o sobie, $25-$ latkowie $-72 \%$, a nastolatkowie $-86 \%$. Mając taką pulę danych o osobie, można wykreować „digitalnego bliźniaka”. To pozwoli na awataryzację relacji dzięki tworzeniu cyfrowych kopii użytkowników, które będą zastępować ludzkich aktorów w transakcjach różnego rodzaju.

Są obawy, że jeśli rozwój człowieka nie będzie towarzyszył rozwojowi techniki, to będzie się ona stawać coraz bardziej autonomicznym systemem, o działaniu którego nie decydują ani wyłącznie, ani przede wszystkim potrzeby i cechy człowieka. W przeważającej większości współczesny „człowiek z ulicy” nie rozumie technologii, jakimi się posługuje, są one dlań owymi Foucaultiańskimi „czarnymi skrzynkami”, stanowiąc przedłużenie bądź wzmocnienie pewnych funkcji jego mózgu, coraz bardziej zmieniają świadomość. Uwolniony spod panowania człowieka rozwój techniki stawia przed nim cele, które są nie tyle celami osoby, ile systemu człowiek-maszyna, czy też systemu ludzie-technika (Bobryk 2014). Amerykański filozof i informatyk Eben Moglen ogłasza narodziny machina universalis, która wszystko o nas wie, podpowiada, jak mamy żyć, i przewiduje nasze dobre oraz złe uczynki (Moglen 2013). Kształty przyszłych społeczeństw zależeć będą od tego, na co pozwolimy technologiom informacyjno-komunikacyjnym, czyli w istocie od kultury społecznej (np. na coraz mniej pozwalamy telewizorom, pozbywanie się ich $\mathrm{z}$ domu jest trendy). Akceptujemy te technologie, co do których jesteśmy przekonani, że ułatwiają nam życie.

Czy era cyfrowa nie sprawi, że przetechnologizowanie naszego życia wywoła technology fatigue? Już przed kilkunastu laty badania w Japonii pokazały lęk przed człekopodobnymi robotami, mimo że Japończycy byli pozytywnie do nich nastawieni. Ale kiedy nasycone inteligencją maszynową roboty wyręczały ludzi w coraz większej liczbie zajęć, także umysłowych, to pojawiał się niepokój: kim ja jestem jako człowiek, czym się różnię od robota? Inżynier i konstruktor robotów, Masahiro Mori, nazwał to „doliną niesamowitości” (Uncanny valley, zapewne w nawiązaniu do Doliny Krzemowej) (Masahiro 2012). Te lęki wyznaczą w przyszłości granice automatyzacji. W zautomatyzowanym szpitalu w Wuhan, redukującym ryzyko zarażenia personelu medycznego, pacjenci łakną kontaktu z żywą pielęgniarką czy lekarzem, brak human touch wywołuje bowiem u nich poczucie deprywacji. Może to oznaczać, że obsługa maszynowa będzie wprawdzie tańsza, ale pacjenci, czy generalnie - użytkownicy automatów, będą woleli 
dopłacić, aby być choć w jakiejś części obsługiwani przez ludzi. To kwestia nie tylko komfortu i poczucia bezpieczeństwa, lecz także statusu społecznego.

\section{Zakończenie}

Czy ma to dobre strony? Zależy, jak na to patrzeć: mnożenie działań w obu przestrzeniach - fizycznej i cyfrowej, przyspieszenie rytmu życia, wypełnia próżnię istnienia, człowiek nie zadaje sobie "głupich" pytań o sens życia. Natura info-tech to z jednej strony przyrost wolności, z drugiej wszakże kontrola, szybkość i władza, czyli cechy, które nie są zwykłym ludziom przyjazne i do których niełatwo się przystosować. Nacisk na ciągłe nabywanie nowych umiejętności i kompetencji, czyli poszerzanie kapitału ludzkiego, wzmaga bóle adaptacji.

Po wynalezieniu i upowszechnieniu druku polityka, ekonomia, kultura i wszystkie inne dziedziny życia miały kilka wieków spokoju, który wykorzystały na rozwój szkolnictwa, demokracji itp. Teraz takiego komfortu nie mają; systemy regulacji są zawsze opóźnione o jedną fazę. Dziś ważniejsza jest szybkość i kontrola dostępu niż kontrola przestrzeni przez politykę. Technologia też nie ma czasu na doskonalenie.

Jedną ze strategii jest dążenie do stawienia czoła wyzwaniom, aktywna adaptacja, pogoń za nowinkami, inwestowanie w siebie, ciągła samoaktualizacja pochłaniająca dużo czasu i energii, aby nadążyć; być w kursie, być „debeściakiem”. Na bok odkłada się inne sprawy, m.in. założenie rodziny. Jeśli potrzebna jest większa wydolność organizmu, to nie stroni się od „podrasowywania” psychiki. Odpowiednich treningów i specyfików jest pod dostatkiem. Trzeba mknąć autostradą, z której nie ma zjazdów.

Inna wizja to dać się ponieść fali; korzystać z przyjemności, jakie oferują technologie, zanurzyć się w rozrywce, grach, żyć chwilą, nieustannie czegoś doświadczać. Jest to eskapizm; ucieczka od wysiłku mierzenia się z wyzwaniami, folgowanie zachciankom i popędom.

Trzecią koncepcją jest próba prawdziwej ucieczki, szukania alternatywy, niepoddawanie się systemowi, w którym człowiek jest jak cegła wbudowana w ten system - jeśli zmurszeje, musi szybko zostać wymieniona, wydalona do środowiska. Jest wiele oznak, że takie ucieczki są coraz częstsze. Jest gdzieś granica adaptacji. Czy przy tej szybkości można być 
aktywnym przez długi czas, czy ludzie się przystosują do terroru kompetencji niewyobrażalnych jeszcze jedno pokolenie wstecz? W którymś momencie ekstensje naszych zmysłów i umysłu sprawiają, że sami stajemy się produktami sieciowymi, podróżującymi tam i z powrotem.

Narzuca to pytanie o podmiot w sytuacji, gdy brak mu stałych znaczeń i wszystko jest negocjowalne. Co się z nim dzieje w sieci intensyfikującej relacje społeczne, w owej wirtualności rzeczywistej, którą cechuje brak centrum, względność wszystkiego, pluralizm prawd, iluzja, spektakl wbudowany w kulturę, reprodukcja i konsumpcja, rozmycie w mobilności i hiperkomunikacji? Czy taki podmiot znika, czy może tylko przekształca się w jakiś inny. Jaki? Nad wszystkim unosi się imperatyw owej hiperkomunikacji, który robi niezwykłe rzeczy ze wszystkim.

Przyszłość jeszcze bardziej to skomplikuje, a przyczyniają się do tego technologie sieciowe nowej generacji (5G). Japonia ogłosiła przed kilku laty budowę społeczeństwa 5.0 opartego o te technologie. Nie są to już tylko sieci komórkowe służące głównie komunikacji interpersonalnej, lecz także wszechobejmującej komunikacji między ludzkimi i nie-ludzkimi (przedmiotami) aktorami, a także między przedmiotami (Internet rzeczy). 5G ma rozwiązać wiele problemów związanych m.in. ze starzeniem się społeczeństwa. Technologie sieciowe tej generacji będą podstawą przemysłów przyszłości (Ross 2017).

Zwolennicy 5.0 argumentują, że różnica leży w kondycji człowieka. W społeczeństwie informacyjnym powszechną praktyką było (w istocie nadal jest) pozyskiwanie przez ludzi danych za pośrednictwem sieci oraz ich przetwarzanie za pomocą narzędzi informatycznych, analizowanie, interpretowanie, destylowanie, kontekstualizowanie, agregowanie, czyli przekształcanie danych $w$ informację i integrowanie jej z posiadaną już wiedzą. W społeczeństwie 5.0 ludzie, rzeczy, systemy, przyroda są połączone w cyberprzestrzeni i uzyskują optymalne rezultaty dzięki sztucznej inteligencji, jej niedostępnemu człowiekowi potencjałowi analitycznemu. Po pozyskaniu, przetworzeniu i przeanalizowaniu danych ze świata fizycznego $\mathrm{w}$ chmurze przez AI powracają one do świata materii, wprawiając $\mathrm{w}$ ruch urządzenia autonomiczne, pojazdy, boty i inne. Komunikujące się ze sobą maszyny w ramach Internetu rzeczy są podstawą przemysłu 4.0 in. To przynosi wcześniej nieosiągalną nową wartość gospodarce i społeczeństwie. W zakładach, które są na ścieżce przechodzenia na produkcję cyfrową - produktywność technologiczna rośnie średnio o 5\% rocznie. Należy spodziewać się, że w ciągu najbliższej dekady większość produkcji będzie 
mogła być realizowana w trybie 24-godzinnym przez 7 dni w tygodniu. Prowadzi to bezpośrednio do radykalnego wzrostu efektywności maszyn, systemów i zasobów, jak również zarządzania produkcją, planowaniem zmian technologicznych itd. ${ }^{4}$ Zmieni to postrzeganie zawodu - to będzie zapotrzebowanie nie tyle na nowe zawody, ile na wiązki nowych kompetencji.

SARS-CoV2 okazał się potężnym akceleratorem rozwoju technologii. Przyspiesza on procesy, które bez niego rozwijałyby się wolniej: zdalna praca i edukacja, e-usługi, e-handel, e-bankowość i inne. W niektórych obszarach usług cyfrowych ich dynamika, którą przed pandemią szacowano na lata, odnotowano zaledwie w ciągu kilku dni czy tygodni. Według danych ruch sieciowy w Europie urósł już na początku pandemii o 30\% w stosunku do analogicznego okresu z 2019 r. Dwukrotny przyrost odnotowano $\mathrm{w}$ obszarze ruchu generowanego przez gry komputerowe i oprogramowanie służące do przeprowadzania wideokonferencji. Liczba wiadomości wysyłanych za pośrednictwem WhatsAppa zwiększyła się z kolei aż czterokrotnie (Olanicki 2020). Przy tej dynamice przeciążenie Internetu bazującego na dotychczasowych generacjach technologii sieciowych (3G i 4G) jest tylko kwestią czasu. Jedynym ratunkiem są zatem sieci nowej generacji (5G). Sceptycy muszą sobie odpowiedzieć na pytanie, czy godzimy się na paraliż sieci, czy akceptujemy wyzwania i problemy związane $\mathrm{z}$ tą nową generacją (m.in. wzrost promieniowania elektromagnetycznego, czym straszy się użytkowników). Kluczowa wydaje się adaptacja odbiorców do wymogów tej technologii. Powinna być ona proaktywna, antycypacyjna (uprzedzające programy edukacyjne w szkołach, szkolenia, treningi i inne), a nie reaktywna - „wzięcie przez zaskoczenie” powodujące stresy itp. Ta druga kieruje energię człowieka nie na osobniczą ekspansję, a na przetrwanie siebie i bliskich, czyli koncentruje uwage na niższych szczeblach hierarchii Maslowa.

Co więc $z$ tą naszą cywilizacją wysoce stechnologizowaną? Od dawna wysyła ona sprzeczne sygnały. Z jednej strony - i to jest dawno odkryty truizm - technologie rozwiązują mnóstwo problemów, ale jednocześnie

4 Nadzieje pokłada się w technologiach blockchain. Związane jest to z rozwojem usług w chmurze. Klient „zawiesza” w niej zadanie, a profesjonalista je stamtąd pobiera, rozwiązuje i poprzez nią pobiera wynagrodzenie. Szacuje się, że docelowo w łańcuchach blokowych znajdzie się ok. 500 mln specjalistów - freelancerów, co zmieni zasadniczo gospodarowanie zasobami ludzkimi i ułatwi pracę rekruterom, którzy będą mogli zamawiać pakiety usług eksperckich, obliczeniowych, programistycznych i inne. 
rodzą nowe i to takie, których bez upowszechnienia technologii by nie było. Zwrócił na to uwagę przed ośmioma laty Bill Davidow, który w książce Overconnected. Threats and promise of the Internet (2012) pisal, że sieci wskutek hiperkomunikacji, czyli potęgowego rozkładu interakcji, przyspieszają wszystko na dobre i na złe - takie jest ich janusowe oblicze. Przyspieszają kryzysy, globalizują je. Technologiom sieciowym, które czynią wszystko połączalnym, B. Davidow przypisywał rozprzestrzenianie się kryzysów na rynkach finansowych w $2008 \mathrm{r}$. Z powodu gęstości połączeń świat stał się wiralny - cechuje go logika zarazy, jak wirusy rozprzestrzeniają się memy, fakenewsy i niemal wszystko inne. Epidemia, infekcja oprócz ich medycznego znaczenia były zawsze metaforą rozprzestrzeniania się wzorców społecznych i kulturowych. Krytyczny punkt, od którego taka infekcja nabiera dynamiki, Malcolm Gladwell nazwał tipping point (punkt przełomowy, zwrotny). Nie chodzi tylko o sieci komputerowe, ale wszelkie inne, $\mathrm{w}$ tym sieci transportu - ludzi i rzeczy, które na skutek owego potęgowego rozkładu interakcji potrafią przenosić koronawirus w postępie geometrycznym, zarażając w krótkim czasie niemal całą planetę. Taka jest moc mnożnika sieciowego. Na razie technologie, w tym medycyna, nie radzą sobie z tym. Nie radzi sobie też sztuczna inteligencja, w którą tak wierzymy. Była nadzieja, że Google Flu Trends zaalarmuje o każdej nowej epidemii grypy. Okazała się ona jednak płonna.

Technika przestanie być narzędziem, stanie się częścią systemu technoludzkiego, który ma wartość tylko jako całość, każdy z podsystemów w pojedynkę będzie bezwartościowy. Do tego potrzeba coraz lepszych interfejsów dla człowieko-maszyny („głowokomputera”). Nie będzie wtedy sensu mówić, że urządzenie cyfrowe jest narzędziem człowieka; człowiek sam stanie się poniekąd metanarzędziem - narzędziem narzędzia.

Żeby zwolnić, cywilizacja musi wytworzyć jakieś antyciała; kultura musi oswoić każdą nową zmianę, ciągle dopasowywać się do błyskawicznie starzejących się technologii. Zwolnić tempa chyba się już nie da. Między innymi za przyczyną sieci. Jej rozwój ma swoją logikę, która nieuchronnie prowadzi do totalnej technicyzacji świata. Człowiek staje się w efekcie elementem systemu, węzłem totalnej sieci, która redukuje go do wymiaru zoon technikon, zwierzęcia technicznego. Połączenia między jej węzłami gęstnieją w coraz szybszym tempie, by w końcu zdusić nowoczesną cywilizację w śmiertelnym uścisku. Innymi słowy, „,Matrix to my”.

Burzliwa historia techniki zawsze dowodziła olbrzymich zdolności adaptacyjnych człowieka. Potrafił przystosować się, choć nie bez szkód 
społecznych (m.in. anomia), do taśmy produkcyjnej. Jest pytanie, czy te zdolności psychofizyczne pozwolą mu na taką adaptację do hiperkomunikacji. Szanse widzi się w tym, że wymierają "pokolenia analogowe", do głosu dochodzą cyfrowe - „komputerowe dzieci i obywatele sieciowi”, zorientowani na przyszłość, o osobowości radarowej, która kieruje nas tam, skąd $\mathrm{w}$ danym momencie dochodzą najsilniejsze impulsy informacyjne, a one nadchodzą z cyberprzestrzeni. Co będzie jednak, kiedy nie da się szybciej, nie pozwoli bowiem na to fizjologia i psychika. W jakim kierunku zwróci się człowiek, po jakie nieznane wcześniej moce sięgnie?

Słyszy się opinie, że w systemie człowiek-technika słabszym ogniwem staje się człowiek. Rodzi to dylemat: jeśli dziś ludzie stoją na drodze wzrostu efektywności komputera, to co robić: pozostawić ich samym sobie i udoskonalać technologie, które będą ich zastępować, czy też udoskonalać samego człowieka, żeby nie pozostawał w tyle jako gorszy podsystem $\mathrm{w}$ duecie $\mathrm{z}$ techniką.

To nie jest nowa tendencja, ale tak wielka skala zapośredniczenia relacji, z jaką mamy dziś do czynienia, jest bezprecedensowa. Przyszłość pokaże, w jakim kierunku pójdzie ten trend cywilizacyjny. Chyba tego nikt nie zmierzył, ale można założyć, że mediatyzacja przerosła skalę interakcji face-to-face, jeśli brać pod uwagę relacje pozarodzinne. Taka komunikacja w sytuacji ograniczeń kontaktów w świecie fizycznym pełni ważną rolę terapeutyczną, zaspokaja potrzebę bycia w społeczności. Wyraża się ona $\mathrm{w}$ wirtualnej stadności. To nie jest oczywiście to samo, ale działa jako substytut. Zoon politicon stał się e-zoon technikon.

Zdaniem niektórych badaczy trwały rozwój technologiczny doprowadzi do tego, że w przyszłości dominującą formą kontaktów międzyludzkich będzie nie wirtualna stadność, a wspomniany indywidualizm sieciowy. Prowadzi doń hipermedium - komputer i każde inne urządzenie sieciowe. Dla kilku miliardów ludzi (użytkowników komórek/smartfonów na globie jest ok. 6 mld) jest ono już dziś narzędziem najważniejszym, dla którego trudno znaleźć precedens w historii cywilizacji technicznej. Z takiego narzędzia każdy może zrobić własny użytek, wykreować osobisty, niepowtarzalny świat, "przepuścićc je przez swój filtr mentalny i kulturowy, tworzyć prywatne reprezentacje, za pomocą których jednostki organizują otaczający je świat i nadają mu znaczenia; słowem: spersonalizować, co nie było możliwe w epoce maszyn, które algorytmizowały ich użycie przez ludzi. 


\section{Bibliografia}

Afeltowicz, Ł., K. Pietrowicz (2013), Maszyny społeczne. Wszystko ujdzie, o ile działa, (Warszawa: Wydawnictwo Naukowe PWN).

Anissimov, M.M. (2015), Our Accelerating Future. How Superintelligence, Nanotechnology, and Transhumanism Will Transform the Planet, (Duluth: Zenith Books).

Attali, J. (2008), Krótka historia przyszłości, (Warszawa: Prószyński i S-ka).

Bobryk, J. (2014), Transhumanizm, „cognitive science” i wyzwania dla nauk społecznych, "Studia Socjologiczne" 3: 9-27.

Brin, D. (1998), The Transparent Society. Will Technology Force Us To Choose Between Privacy And Freedom? (New York: Perseus Books).

Castells, M. (2011), Społeczeństwo sieci, (Warszawa: Wydawnictwo Naukowe PWN).

Davidow, W.H. (2012), Overconnected. Threats and promise of the Internet, (Santa Monica: Delphinium Books).

Domingos, P. (2017), The Master Algorithm. How the Quest for the Ultimate Learning Machine Will Remake Our World, (London: Penguin Books).

Innis, H. (1951), The Bias of Communication, (Toronto: University of Toronto Press).

Kosmiczny internet coraz blizej. Na orbite dostarczono kolejne satelity Starlink od SpaceX (2020), https://biznes.wprost.pl/technologie/internet/10351081/kosmiczny-internet-coraz-blizej-na-orbite-dostarczono-kolejne-satelity-starlink-odspacex.html (7.08.2020).

Krzysztofek, K. (2018), Digital Power. Zmieniajace się relacje sity w społeczeństwie danych-informacji-wiedzy, [w:] L. Zacher (red.), Potencjaty i relacje sit w cyfrowym społeczeństwie wiedzy, (Warszawa: Wydawnictwo Poltext):73-110.

Manovich, L. (2013), Software takes command, (New York: Bloomsbury Acadamic).

Masahiro, M. (2012), The Uncanny Valley: The Original Essay by Masahiro Mori, http://spectrum.ieee.org/automaton/robotics/humanoids/the-uncanny-valley (7.04.2017).

Moglen, E. (2013), Wolność w chmurze i inne eseje, (Warszawa: Fundacja Nowoczesna Polska).

Morozov, E. (2013), To Save Everything, Click Here. Technology, Solutionism, and the Urge to Fix Problems that Don't Exist, (London: Allen Lane).

Rainie, L., B. Wellman (2012), Networked. The New Social Operating System, (Cambridge: MIT Press).

Ross, A. (2017), Industries of the Future, (London: Simon \& Shuster).

Sesame Credit. Data-Driven Credit Scoring (2016), http://fintechnews.sg/1302/fintech/sesame-credit-data-driven-credit-scoring/ (30.12.2018).

Shadbolt, N.R. (2013), Knowledge acquisition and the rise of social machines, „International Journal of Human-Computer Studies" 71(2): 200-205. 
Smart, P.R., N.R. Shadbolt (2014), “Social Machines.", [w:] M. Khosrow-Pour (red.), Encyclopedia of Information Science and Technology, (Hershey: IGI Global): 6855-6862.

Stawska, K. (2021), Internet, jakiego nie znamy, dzięki 6G. Padła data, https://tech. wp.pl/internet-jakiego-nie-znamy-dzieki-6g-padla-data-6614763926350464a (5.03.2021).

Strittmatter, K. (2020), Chiny 5.0. Jak powstaje cyfrowa dyktatura, (Warszawa: Wydawnictwo W.A.B.).

Sumpter, D. (2019), Osaczeni przez l1cz3y. O algorytmach, które kontrolują nasze życie. Od Facebooka i Google'a po fake newsy i bańki filtrujące, (Kraków: Copernicus Center Press).

Walewski, Ł. (2020),Wł@dza w sieci. Jak nami rządzą social media, (Kraków: Mando).

Webb, A. (2019), The Big Nine. How the Tech Titans and Their Thinking Machines Could Warp Humanity, (New York: PublicAffairs).

Wellman, B. (2001), Physical Place and Cyberplace. The Rise of Personalized Networking, „International Journal for Urban and Regional Research", 25(2): 227-252.

Wu, T. (2010), The Master Switch. The Rise and Fall of Information Empires. New York: Alfred A. Knopf). 
